\title{
Features of sales promotion in cigarette magazine advertisements, 1980-1993: an analysis of youth exposure in the United States
}

\author{
Linda G Pucci, Michael Siegel
}

\begin{abstract}
Objective-To examine the presence of features of sales promotion in cigarette advertising in United States magazines, and to describe trends in youth (ages 12-17) exposure to such advertising (termed "promotional advertising").

Design-Analysis of 1980-1993 annual data on: (a) total pages and expenditures for "promotional advertising" (advertising that contains features of sales promotion) in 36 popular magazines (all magazines for which data were available), by cigarette brand; and (b) readership characteristics for each magazine. We defined promotional advertising as advertisements that go beyond the simple advertising of the product and its features to include one or more features of sales promotion, such as coupons, "retail value added" promotions, contests, sweepstakes, catalogues, specialty item distribution, and sponsorship of public entertainment or sporting events.
\end{abstract}

Main outcome measures-Total pages of, and expenditures for promotional advertising in magazines; and gross impressions (number of readers multiplied by the number of pages of promotional advertising) among youth and total readership.

Results-During the period 1980-1993, tobacco companies spent $\$ 90.2$ million on promotional advertising in the 36 magazines. The proportion of promotional advertising appearing in "youth" magazines (defined as magazines with a greater than average proportion of youth readers) increased from $7 \%$ in 1980 to nearly $100 \%$ in 1987 . Although youth readers represented only $19 \%$ of magazine readers, the proportion of youth gross impressions to total gross impressions of tobacco promotional advertising exceeded this value throughout the entire period $1985-1993$, peaking at $33 \%$ in 1987 . The five "youth" cigarette brands (defined as brands smoked by at least $2.5 \%$ of smokers aged 10-15 years in 1993) accounted for $59 \%$ of promotional advertising in all magazines, but for $83 \%$ of promotional advertising in youth magazines during the study period.

Conclusions-In their magazine advertising, cigarette companies are preferentially exposing young people to advertise- ments that contain sales promotional features.

(Tobacco Control 1999;8:29-36)

Keywords: advertising; magazines; adolescents

\section{Introduction}

Cigarette marketing has been implicated as one cause of smoking initiation among adolescents. ${ }^{1}$ Cigarette marketing, however, is not a homogenous entity, and thus cannot be studied or counteracted as such. It consists of a variety of techniques that must be considered separately and in concert with each other. Promotion-the communication mechanism of marketing ${ }^{2}$ - can take four different forms: (a) advertising; (b) personal selling; (c) public relations; and (d) sales promotion. ${ }^{2-4}$ Sales promotion itself consists of a variety of promotional tools that are not classifiable as advertising, personal selling, or public relations. $^{3}$ These include free samples, coupons, money-refund offers, prices-off, premiums, contests, sweepstakes, trading stamps, demonstrations, event sponsorship, and provision of free merchandise and other incentives to store owners. ${ }^{23}$ Effective product promotion requires the integration of these different forms of promotion (the marketing literature calls this "integrated marketing communications". ${ }^{3}$ Determining the marketing mix, or the proportion of the marketing budget devoted to advertising, personal selling, public relations, and sales promotion, represents a key marketing strategy decision. ${ }^{2}{ }^{3}$

The Joe Camel campaign, for example, introduced in the United States in 1988, consisted of a combination of advertising and sales promotion. According to RJ Reynolds documents, the campaign was initiated by giving away Camel teeshirts and lighters (sales promotion), combined with a print advertising campaign in magazines appealing to young people and an outdoor advertising campaign at locations where young people congregate. ${ }^{5}$ Camel continues to use a variety of sales promotion (specialty item distribution, coupons, contests, sweepstakes, Camel cash, catalogues, premiums, event sponsorship, and provision of merchandise and incentives to retailers) and advertising (newspaper, magazine, outdoor, and transit advertising) techniques to promote its product.

Previous research has tended to consider cigarette advertising and sales promotion as distinct entities. In fact, the Federal Trade Commission (FTC) separates cigarette 
marketing expenditures into an advertising (newspaper, magazine, outdoor, and transit) and a "promotions" (point of sale advertising, promotional allowances, sampling distribution, specialty item distribution, public entertainment, coupons and retail value added promotions, and direct mail marketing) component. ${ }^{6}$ However, advertising and sales promotion techniques may overlap and be used together as a single vehicle to promote cigarettes. For example, cigarette companies may use magazine advertisements as a platform to increase consumer participation in promotions such as collection of coupons to redeem for tobacco specialty items. Magazine advertisements may also be used to publicise other sales promotion offers, such as money-back offers, or to announce events being sponsored by cigarette companies. Treating all magazine advertising as simply "advertising" may be misleading, because advertisements that have features of sales promotion may differ in terms of their marketing roles, their target audiences, and their effects on specific population subgroups, such as young people. Certain sales promotion techniques, for example, have been shown to be highly appealing to young people, ${ }^{17}$ so the presence of features of sales promotion in magazine advertising could reflect an attempt to appeal to young readers. Sales promotional techniques, such as tobacco specialty item distribution, have also been found to have a strong influence on smoking behaviour in young people. ${ }^{8}$ Thus, if cigarette advertising in magazines includes a large sales promotional component, then such advertising may have more of an influence on smoking behaviour than previously thought, especially among young people.

In this paper, we make a first attempt to study specifically the tobacco companies' use of sales promotional features in magazine advertising for cigarettes. For the purposes of this paper, we define "promotional advertising" in magazines as advertising that includes a sales promotional component. In other words, promotional advertisements would include those advertisements with one or more features of sales promotion, such as coupons, "retail value added" promotions (such as "buy one, get one free"), contests, sweepstakes, catalogues, specialty item distribution, and sponsorship of public entertainment or sporting events. Because all advertising represents a form of promotion, we use the term "promotional advertising" in this paper simply to avoid having to repeat the phrase "advertising that contains features of sales promotion". By examining patterns of brandspecific promotional advertising in magazines in relation to the youth (ages 12-17) readership of a large sample of magazines, we aim to describe young people's exposure to magazine promotional advertising and to examine evidence that cigarette companies may be specifically targeting the young with this type of advertising.

Examples of what we term "promotional advertising" in magazines include an advertise-

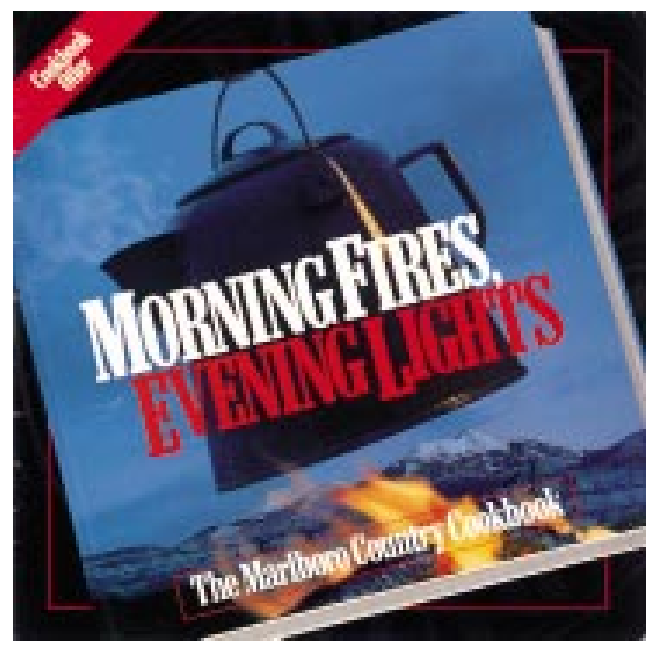

Figure 1 Example of a magazine advertisement containing features of sales promotion: advertisement for a "Marlboro country cookbook" that can be ordered by trading in 300 Marlboro miles (this requires purchasing a total of 60 cigarette packs). From "Car \& Driver", November 1998.

ment for a Marlboro country cookbook, which can be ordered by trading in 300 Marlboro miles (this requires purchasing a total of 60 cigarette packs) (figure 1) and an advertisement for a Camel "Mighty Tasty Lifestyles" sweepstakes, with prizes including a 28 -foot (8.5-metre) "cigarette boat", a fully loaded Dodge Viper sports car, and three months in Malibu, California (figure 2).

To the best of our knowledge, there has been no published analysis of the nature and extent of promotional magazine advertising by cigarette companies or brands. Previous studies of the content of cigarette advertisements in magazines have focused on the themes, images, and models used in these advertisements. $^{9-17}$ However, none of these studies reported on the presence of sales promotional features (such as coupons, specialty item distribution, or sponsorship of public entertainment and sporting events) in these advertisements.

In this study, we report the total number of pages and expenditures for cigarette promotional advertising in a sample of 36 popular American magazines (all magazines for which data were available) during the period 1980-1993. In addition to describing the magnitude and trends in such advertising, we examine differences in promotional advertising in magazines for cigarette brands that are popular among young people ("youth" brands) compared with those smoked almost exclusively by adults ("adult" brands). We report data not only on the extent of promotional advertising in magazines, but on the distribution of this advertising among magazines with varying levels of youth readership. In this way, we are able to analyse trends in exposure of the young to promotional advertisements in magazines as well as differences in the patterns of promotional advertising for youth and adult cigarette brands.

The results of such an analysis have implications not only for the question of 


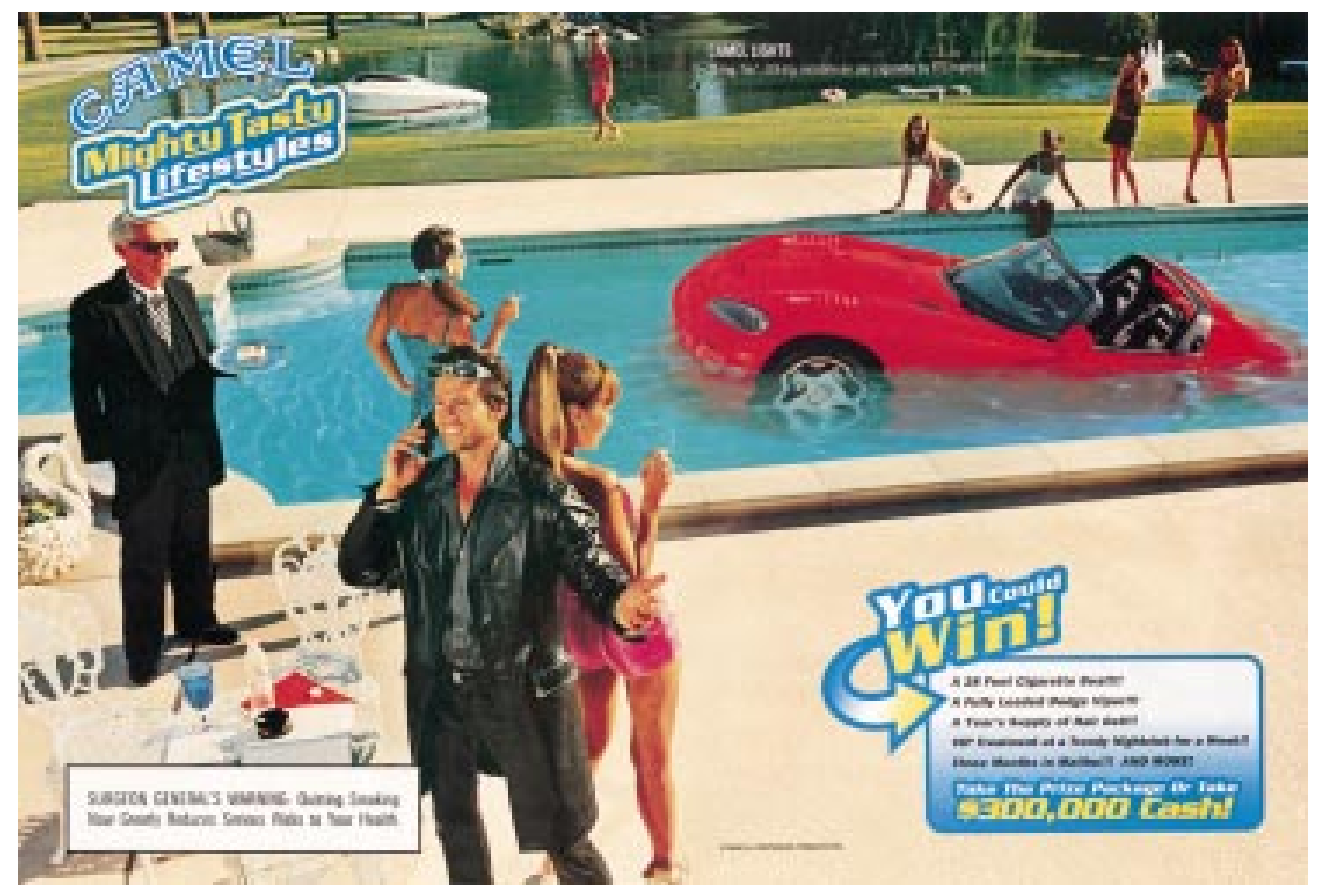

Figure 2 Example of a magazine advertisement containing features of sales promotion: advertisement for a Camel "Mighty Tasty Lifestyles" sweepstakes, with prizes including a 28-foot (8.5-metre) "cigarette boat", a fully loaded Dodge Viper sports car, and three months in Malibu, California. From "McCalls", November 1998.

whether cigarette companies are targeting young people in their magazine advertising, but also for the question of what impact such advertising has on the young. Previous studies have demonstrated that young people tend to be highly involved in tobacco sales promotional campaigns $^{17^{18-20}}$ and that experience with tobacco sales promotions (especially specialty item distribution) is strongly associated with their susceptibility to tobacco use $\mathrm{e}^{20-22}$ and with smoking experimentation. ${ }^{8}$ Thus, the true impact of cigarette advertising in magazines on young people cannot be understood without first characterising the nature and extent of sales promotional features embedded in this advertising.

\section{Methods}

Most tobacco advertising in magazines relates strictly to the features of tobacco products and does not have a promotional component. For the purposes of this paper, we defined promotional advertising as advertisements that go beyond the simple advertising of the product and its features to include one or more features of sales promotion, such as coupons, retail value added promotions, contests, sweepstakes, catalogues, specialty item distribution, and sponsorship of public entertainment or sporting events. Thus, promotional advertising encompasses: (a) contests, sweepstakes, coupons, and retail value added promotions such as premiums and rebates-for example, cents-off coupons, multiple pack promotions, and retail value added offers such as "buy one, get one free"; (b) specialty item advertising for articles such as teeshirts, caps, sunglasses, keychains, calendars, lighters and sporting goods with a brand's logo to be sold or given away to consumers and catalogues advertising this merchandise; and (c) special activities such as fashion/achievement awards, public entertainment, or sporting events sponsored by tobacco companies.

MAGAZINE SAMPLE SELECTION

The data available to us included brandspecific advertising data for a sample of the major American magazines during the period 1980-1993 (provided by Leading National Advertisers (LNA) ${ }^{23}$ ), adult readership data for a large sample of magazines during the period 1986-1993 (obtained from Simmons Market Research Bureau, ${ }^{24}$ ), and youth (ages 12-17) readership data for a large sample of magazines for the years 1986-1993 (obtained from Teenage Research Unlimited ${ }^{25}$ and from Mediamark Research. ${ }^{26}$ ). To select a sample of magazines for analysis, we identified all magazines for which data on adult and youth readership and data on brand-specific cigarette advertising were available for the years 1986-1993. The final sample consisted of 36 magazines. The sample was similar to the magazine sample described in a previous paper, ${ }^{27}$ except that three magazines (Entertainment Weekly, Harper's Bazaar, and Ladies Home Fournal) were eliminated because readership data were not available for most of the study period.

It is unlikely that there is any significant sampling bias that would affect our results, since we chose the sample magazines in advance of the analysis and used a clear criterion for inclusion of magazines in the study: the availability of brand-specific advertising expenditure data and adult and youth readership data covering the time period 1986-1993. Moreover, our sample contains $72 \%$ (36) of the top 50 magazines (in terms of overall readership levels) that accept tobacco advertising and that are covered by Simmons Market Research Bureau, in its annual readership surveys. Finally, we noted 
that very few promotional cigarette advertisements reported by LNA appeared in magazines that were not covered in our magazine sample.

Although we did not have youth readership data available for the years 1980-1985, we did have cigarette advertising data available for those years. Rather than restrict the analysis to the period 1986-1993, we chose to include these years in our analyses, but to use the 1986 readership data to classify magazines as "adult" or "youth" magazines for those years. Thus, we applied the classification of magazines as "adult" or "youth" magazines in 1986 to the years $1980-1985$. The percentage of youth readers for the magazines in our sample did not change substantially during the period 1986-1993, and we therefore do not believe the classification of magazines into "youth" or "adult" magazines would have differed substantially had actual readership data for the years 1980-1985 been available.

DATA SOURCES

Pages and expenditures for promotional

advertising

From the LNA's Brand detail reports for the years 1980 to $1993,{ }^{23}$ we obtained the number of advertising pages and total expenditures devoted to coupons/retail value added promotions, specialty item distribution, and advertisements for public entertainment and events sponsored by tobacco companies for each brand in each of the magazines included in the LNA study. The LNA study records data not only on the number of pages and expenditures for cigarette advertising in magazines, but also on the nature of the advertising (whether the advertising includes a sales promotional component, and if so, for what type of sales promotion). Expenditures reported by LNA are based on the number of pages of advertising and the price per advertising page for the magazine, not on actual dollars negotiated with a publisher. Pages are reported as fractions because cigarette advertisements often comprise less than a full magazine page.

\section{Magazine readership}

Data on adult (ages 18 and older) readership for each magazine during the years 1986 through 1993 were obtained from the Study of media and markets, produced by Simmons Market Research Bureau, ${ }^{24}$ Data on youth (ages 12-17) readership, stratified by gender and race, were obtained from Teenage Research Unlimited ${ }^{25}$ and from Mediamark Research. ${ }^{26}$ These data were available only for the years 1986 through 1993 .

DEFINITIONS

A "youth" magazine was defined as one whose proportion of young readers was greater than the overall average youth readership among all 36 magazines for the year in question. For example, in 1980, the average youth readership for all 36 magazines was $22 \%$, so any magazine with a youth readership of $22 \%$ or higher was classified as a "youth" magazine. This classification was not intended to imply that there is a demarcation between the age-orientation of these magazines at the cut-off value. Rather, we desired to divide all magazines into "youth" or "adult" categories to examine the distribution of brand-specific cigarette promotional advertising among these magazines.

We further divided "youth" magazines by their gender orientation. A "female-youth" magazine was defined as a youth magazine (by the above criterion) with $70 \%$ or more female readership (defined as the proportion of all young readers who are female). A "maleyouth" magazine was defined as a youth magazine with $70 \%$ or more male readership (defined as the proportion of all young readers who are male). Thus, youth magazines whose young readers consisted of more than $70 \%$ females were classified as "female-youth" magazines, those whose young readers consisted of less than $30 \%$ females were classified as "male-youth" magazines, and those whose youth readers consisted of between 30\% and $70 \%$ females were not further classified as either "male-youth" or "female-youth" magazines. We chose $70 \%$ as a cut-off because it marked a natural break in the distribution of gender-specific youth readership among the magazines.

Because youth magazine readership data was available only for the years 1986 and later, we used 1986 data on youth magazine readership to classify magazines as "youth", "maleyouth", and "female-youth" magazines for the years 1980 through 1985 .

The average percentage of young readers among all 36 magazines (the cut-off value used to classify magazines as "adult" or "youth" magazines in a given year) ranged from $17 \%$ to $22 \%$ during the study period. The number of "youth" magazines in a given year ranged from 15 to 17 . The number of "male-youth" magazines in a given year ranged from six to nine. The number of "female-youth" magazines in a given year ranged from four to five.

To assess and compare the exposure young people and adults have to promotional advertisements in popular magazines, we calculated the total gross impressions for such advertising by multiplying the actual number of promotional pages by the number of adults or young people reading the magazine in a given year. This is a standard technique for assessing potential exposure to advertising. ${ }^{3}$ In evaluating gross impressions, a potential exposure means that a member of the target audience was exposed to the medium carrying the advertisement, not that he or she actually viewed the advertisement. ${ }^{3}$ We expressed the ratio of youth to total exposure as the ratio of total gross impressions among young people (which we called youth gross impressions) to the total gross impressions for both youth and adults (which we called total gross impressions). Again, we used 1986 adult and youth readership data to calculate gross impressions for the years 1980-1985.

BRAND CLASSIFICATION

We classified cigarette brands as youth brands or adult brands using a classification scheme 
Table 1 Trends in cigarette promotional advertising in 36 magazines, 1980-1993

\begin{tabular}{|c|c|c|c|c|c|c|}
\hline \multirow[b]{2}{*}{ Year } & \multicolumn{2}{|c|}{$\begin{array}{l}\text { Advertising expenditures, } 36 \text { magazines } \\
\text { (US\$ million) }\end{array}$} & \multicolumn{4}{|c|}{ Pages of cigarette promotional advertising } \\
\hline & All advertising & $\begin{array}{l}\text { Promotional (\% of } \\
\text { total advertising) }\end{array}$ & $\begin{array}{l}36 \text { Magazines } \\
n\end{array}$ & $\begin{array}{l}\text { All youth } \\
\text { magazines* } \\
n(\%)\end{array}$ & $\begin{array}{l}\text { Male-youth } \\
\text { magazinest } \\
(\%)\end{array}$ & $\begin{array}{l}\text { Female-youth } \\
\text { magazinest } \\
(\%)\end{array}$ \\
\hline 1980 & 115.8 & $6.9(6.0)$ & 93.1 & $6.8(7.3)$ & 43 & 54 \\
\hline 1981 & 115.6 & $4.3(3.7)$ & 69.1 & $14.0(20.3)$ & 93 & 7 \\
\hline 1982 & 153.6 & $7.3(4.8)$ & 94.9 & $28.5(30.0)$ & 98 & 2 \\
\hline 1983 & 127.6 & $7.0(5.5)$ & 61.1 & $23.1(37.8)$ & 76 & 24 \\
\hline 1984 & 133.9 & $11.8(8.8)$ & 226.9 & $65.4(28.8)$ & 58 & 42 \\
\hline 1985 & 161.0 & $10.6(6.6)$ & 166.4 & $67.2(40.4)$ & 76 & 24 \\
\hline 1986 & 141.1 & $7.5(5.3)$ & 70.1 & $61.1(87.2)$ & 100 & 0 \\
\hline 1987 & 165.0 & $6.6(4.0)$ & 67.7 & $67.4(99.6)$ & 100 & 0 \\
\hline 1988 & 171.2 & $3.1(1.8)$ & 67.0 & $65.7(98.1)$ & 100 & 0 \\
\hline 1989 & 178.3 & $13.5(7.6)$ & 126.7 & $100.3(79.2)$ & 100 & 0 \\
\hline 1990 & 139.6 & $2.1(1.5)$ & 46.1 & $41.1(89.2)$ & 100 & 0 \\
\hline 1991 & 131.9 & $1.7(1.3)$ & 14.2 & $10.2(71.8)$ & 100 & 0 \\
\hline 1992 & 109.0 & $5.2(4.8)$ & 74.3 & 74.1 (99.7) & 100 & 0 \\
\hline 1993 & 130.9 & $2.8(2.1)$ & 12.5 & $7.6(60.8)$ & 61 & 39 \\
\hline Total & 1974.5 & $90.2(4.6)$ & 1189.9 & $632.4(53.1)$ & 84 & 16 \\
\hline
\end{tabular}

From Leading National Advertisers. [24]

*Youth magazines are defined as those whose percentage of youth readers (youth [ages 12-17 years] readers divided by total [ages $\geqslant 12$ years] readers) in a given year is greater than the overall average percentage of youth readers (for all magazines combined) in that year.

†Male-youth magazines are defined as youth magazines with $>70 \%$ male youth readership (the number of male youth readers divided by the total number of youth readers). Female-youth magazines are defined as youth magazines with $>70 \%$ female youth divided by the total number of youth readers). Female-youth magazines are defined as youth $\mathrm{m}$.
readership (the number of female youth readers divided by the total number of youth readers).

described in an earlier paper. ${ }^{27}$ Briefly, we defined youth brands as those smoked by at least $2.5 \%$ of smokers aged $10-15$ years in the Teenage Attitudes and Practices Survey-II (TAPS-II) conducted by the United States Centers for Disease Control and Prevention in $1993 .^{28}$ Adult brands were defined as those smoked by less than $2.5 \%$ of 10 to 15 year olds in TAPS-II. The youth brands were Marlboro (smoked by $42.9 \%$ of youth smokers), Newport (24.6\%), Camel (13.2\%), Kool $(4.1 \%)$, and Winston (2.8\%). All other brands were considered to be adult brands, since they were smoked by less than $2.5 \%$ of $10-15$-year olds.

DATA ANALYSIS

All data were entered into Microsoft Excel spreadsheets and verified by comparing computer printouts with original raw data. Total promotional advertising pages and expenditures were calculated for each company and brand. Exposure to promotional advertising pages (expressed in gross impressions) in magazines by readership characteristics (age, gender, race) was examined. Gross impressions for youth and all readers were then compared.

\section{Results}

During the period 1980-1993, tobacco companies spent $\$ 90.2$ million (accounting for 1189.9 pages) on promotional advertising in the 36 magazines in our sample (table 1). Total expenditures for all cigarette advertising in these 36 magazines during this period were US $\$ 1974.5$ million; promotional magazine advertising accounted for $4.6 \%$ of this total. Tobacco promotional advertising rose sharply, peaking in the mid-1980s, and then declined in the early 1990s. Overall tobacco advertising in the 36 magazines followed a similar pattern, although it peaked in the late 1980s. The proportion of all magazine advertising expendi- tures accounted for by promotional advertising peaked at $8.8 \%$ in 1984 , and again at $7.6 \%$ in 1989.

VARIETY OF PROMOTIONS ADVERTISED IN MAGAZINES

Three types of promotional tobacco advertising appeared in popular magazines between 1980 and 1993: (a) coupons, sweepstakes, contests, premiums, and retail value added promotions; (b) catalogues and specialty item advertising; and (c) advertisements for activities sponsored by tobacco companies. Distinct patterns of promotional advertising for merchandise that would appeal to a particular market segment emerged. In 1982, for example, Philip Morris placed advertisements for "Marlboro Country Store" (clothing) while RJ Reynolds ran "Camel Gear Promo" advertisements. During the same time period Lorillard offered "Kent Club Vacations" and RJ Reynolds sponsored "More Fashion Awards." Between 1984 and 1989, promotional advertising for coupons, premiums, rebates, and specialty items dominated. By 1985, promotional advertising for sporting events, "Champion Series," and "Sports Connection Hotlines" sponsored by tobacco companies began to appear.

YOUTH EXPOSURE TO PROMOTIONAL

ADVERTISING IN MAGAZINES

During the study period, $53.1 \%(632.4)$ of the 1189.9 pages of promotional advertising were placed in youth magazines (table 1), even though these accounted for only $28.6 \%$ of the total readership for all magazines in the sample. In the early 1980 s, relatively few promotional advertisements were placed in youth magazines compared with all the magazines in our sample. The proportion of promotional advertising appearing in youth magazines increased steadily from $7.3 \%$ in 1980 to $99.6 \%$ in 1987 and $98.1 \%$ in 1988 , 


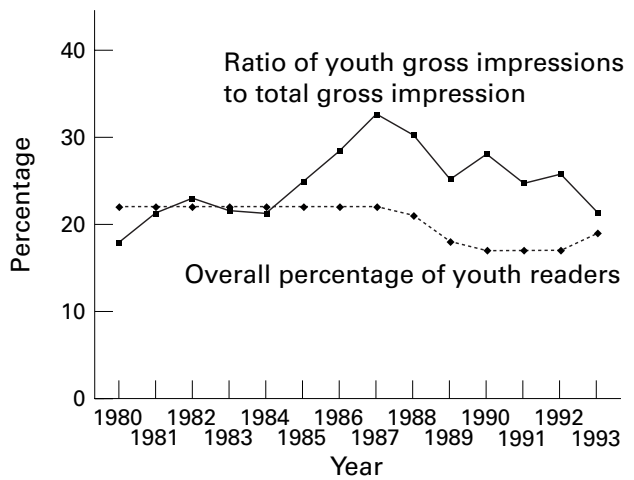

Figure 3 Ratio of youth gross impressions to total gross impressions for cigarette promotional advertisements in 36 magazines and average youth readership in magazines, by year, 1980-1993. Youth gross impressions are defined as the number of pages of advertising in a given magazine multiplied by the number of youth (ages 12-17 years) readers for that magazine, summed over all magazines in a given year. Total gross impressions are defined as the number of pages of advertising in a given magazine multiplied by the total number of readers (ages $\geqslant 12$ years) for that magazine, summed over all magazines in a given year. Youth readership is defined as the total number of youth (ages 12-17 years) readers for all magazines in our sample divided by the total number of readers (ages $\geqslant 12$ years) for all magazines in our sample in a given year. Data from Leading National Advertisers, ${ }^{24}$ Simmons Market Research Bureau, ${ }^{25}$ Teenage Research Unlimited, ${ }^{26}$ and Mediamark Research. ${ }^{27}$

and remained between $60.8 \%$ and $99.7 \%$ during the remainder of the study period.

In 1980 , the 6.8 pages of promotional advertising in youth magazines were almost equally divided between female-youth and male-youth magazines (table 1). However, throughout the remainder of the study period, an overwhelming majority of the promotional advertising was

Table 2 Total pages of cigarette promotional advertising in 36 magazines, 1980-1993, by cigarette company and brand

\begin{tabular}{|c|c|c|c|c|}
\hline \multirow[b]{3}{*}{ Company brand } & \multicolumn{4}{|c|}{ Total pages of cigarette promotional advertising } \\
\hline & \multicolumn{2}{|c|}{ All magazines } & \multicolumn{2}{|c|}{ Youth magazines * } \\
\hline & $\bar{n}$ & $(\%)$ & $n$ & $(\%)$ \\
\hline Philip Morris & 507.3 & 42.6 & 370.9 & 58.6 \\
\hline Marlboro & 414.0 & 34.8 & 349.8 & 55.3 \\
\hline Benson \& Hedges & 46.0 & 3.9 & 4.0 & 0.6 \\
\hline Virginia Slims & 32.0 & 2.7 & 9.0 & 1.4 \\
\hline Merit & 15.0 & 1.3 & 8.0 & 1.3 \\
\hline Concord & 0.3 & 0.0 & 0.1 & 0.0 \\
\hline RJ Reynolds & 319.4 & 26.8 & 193.5 & 30.6 \\
\hline Winston & 116.2 & 9.8 & 83.4 & 13.2 \\
\hline Camel & 77.9 & 6.5 & 58.0 & 9.2 \\
\hline More & 54.6 & 4.6 & 17.0 & 2.7 \\
\hline Salem & 30.3 & 2.5 & 13.4 & 2.1 \\
\hline Vantage & 24.6 & 2.1 & 17.1 & 2.7 \\
\hline Now & 8.8 & 0.7 & 0.0 & 0.0 \\
\hline Premier & 7.2 & 0.6 & 4.7 & 0.7 \\
\hline Brown \& Williamson & 196.8 & 16.5 & 25.0 & 4.0 \\
\hline Belair/Raleigh & 128.6 & 10.8 & 12.9 & 2.0 \\
\hline Kool & 58.2 & 4.9 & 12.1 & 1.9 \\
\hline Viceroy & 10.0 & 0.8 & 0.0 & 0.0 \\
\hline Lorillard & 127.9 & 10.7 & 34.5 & 5.5 \\
\hline Newton & 54.4 & 4.6 & 9.4 & 1.5 \\
\hline Newport & 32.4 & 2.7 & 21.0 & 3.3 \\
\hline Kent & 23.1 & 1.9 & 0.0 & 0.0 \\
\hline True & 18.0 & 1.5 & 4.0 & 0.6 \\
\hline Other companies & 38.5 & 3.2 & 8.5 & 1.3 \\
\hline All youth brands $\dagger$ & 698.7 & 58.7 & 524.4 & 82.9 \\
\hline All adult brandst & 491.2 & 41.3 & 108.0 & 17.1 \\
\hline Total & 1189.9 & & 632.4 & \\
\hline
\end{tabular}

From Leading National Advertisers. [24]

*Youth magazines are defined as those whose percentage of youth readers (youth [ages 12-17 years] readers divided by total [ages $\geqslant 12$ years] readers) in a given year is greater than the overall average percentage of youth readers (for all magazines combined) in that year. +Youth cigarette brands are Marlboro, Camel, Newport, Winston, and Kool (see text for explanation of brand classification). placed in male-youth magazines. From 1986 through 1992, all tobacco promotional advertising appearing in youth magazines was in Car E Driver, Hot Rod, Motor Trend, Road $\mathcal{E}$ Track, Sport, Sporting News, and Sports Illustrated, magazines with predominantly white male readership.

Although youth readers represented approximately $19 \%$ of all magazine readers (for all years combined), the proportion of youth gross impressions to total gross impressions of promotional advertising exceeded this value throughout the entire period from 1985-1993 (figure 3). The proportion of youth gross impressions to total gross impressions was approximately equal to the overall percentage of youth readers (in all magazines combined) during the period 1980-1985, but increased during the late 1980 s, peaking at 33\% in 1987 .

The five youth cigarette brands-Camel, Kool, Marlboro, Newport, and Winstonaccounted for $58.7 \%$ of promotional advertising in all magazines, but for $82.9 \%$ of promotional advertising in youth magazines during the study period (table 2). In contrast, the adult cigarette brands combined accounted for $41.3 \%$ of promotional advertising in all magazines, but for only $17.1 \%$ of promotional advertising in youth magazines. While all adult brands combined placed $22.0 \%$ of their promotional advertising during the period 1980-1993 in youth magazines, the five youth cigarette brands placed $75.1 \%$ of their promotional advertising in youth magazines.

VARIATION IN PROMOTIONAL ADVERTISING BY TOBACCO COMPANY AND CIGARETTE BRAND Of the four tobacco companies that produce youth cigarette brands, Philip Morris dominated in terms of promotional advertising in magazines, having taken out $42.6 \%$ of the promotional pages in all magazines and $58.6 \%$ of the promotional pages in youth magazines during the study period (table 2). More than three quarters of Philip Morris promotional advertising was for Marlboro. Marlboro alone accounted for $34.8 \%$ of promotional advertising in all magazines and $55.3 \%$ of promotional advertising in youth magazines during the study period. In contrast, Philip Morris' other cigarette brands accounted for $7.9 \%$ of promotional advertising in all magazines, but only $3.3 \%$ of promotional advertising in youth magazines. Marlboro accounted for $81.6 \%$ of all Philip Morris promotional advertising during the study period, and for $94.3 \%$ of the company's promotional advertising in youth magazines.

RJ Reynolds was second in promotional advertising, accounting for $26.8 \%$ of the promotional advertising in all magazines and $30.6 \%$ of the promotional advertising in youth magazines (table 2). The company's youth brands (Camel and Winston) together accounted for more than half of its promotional advertising. These two brands accounted for $16.3 \%$ of all cigarette promotional advertising in magazines during the study period, and for $22.4 \%$ of promotional advertising in youth magazines. 
They accounted for $60.8 \%$ of all RJ Reynolds promotional advertising, and for $73.1 \%$ of the company's promotional advertising in youth magazines.

There seemed to be a Camel-Winston trade-off in promotional advertising during the study period. Camel accounted for $44.1 \%$ of RJ Reynolds' total promotional advertising pages and Winston for $2.3 \%$ during the period 1980-1985, but Camel accounted for only $1.1 \%$ of the company's promotional pages during the period 1986-1993, whereas Winston accounted for $76.5 \%$ during this period (data not shown).

Brown \& Williamson was third in promotional advertising. Its youth brandKool-accounted for $29.6 \%$ of the company's promotional advertising in all magazines and for $48.4 \%$ of the company's promotional advertising in youth magazines during the study period. Lorillard was fourth in promotional advertising. Its youth brandNewport - accounted for $25.3 \%$ of the company's promotional advertising in all magazines and for $60.9 \%$ of the company's promotional advertising in youth magazines during the study period.

\section{Discussion}

To the best of our knowledge, this paper is the first to characterise the nature and patterns of tobacco promotional advertising in popular magazines. Our findings show that cigarette companies spent more than $\$ 90$ million on promotional advertising in our magazine sample during the period 1980-1993, representing approximately $4.6 \%$ of their overall advertising budget in these magazines. Promotional advertising for cigarettes in magazines rose sharply during the early 1980s and peaked in 1984, and then decreased in the early 1990s. The proportion of overall magazine advertising consisting of promotional advertising peaked at $8.8 \%$ in 1984 , and again at $7.6 \%$ in 1989 .

The proportion of promotional advertising appearing in youth magazines during the study period was $53.1 \%$, even though these magazines contained only $29 \%$ of the overall readership of all magazines in our sample. Although we found advertising that contained sales promotional features to represent a small proportion of overall cigarette advertising in magazines, the disproportionate presence of this form of advertising in youth magazines may suggest that sales promotional features are included in advertisements intended to appeal to youth readers.

This is also the first study to examine brandspecific patterns of promotional tobacco advertising in magazines in relation to readership characteristics. We found that cigarette brands popular among youth smokers dominated the promotional advertising in youth magazines, accounting for $83 \%$ of all promotional advertising pages taken out by cigarette companies in these magazines. Moreover, although youth readers represented only $19 \%$ of the overall readership of the magazines in our sample, the number of youth gross impressions of tobacco promotional advertising represented as much as $33 \%$ of the overall gross impressions during the study period.

Simply put, our findings demonstrate that young people are being preferentially exposed to cigarette promotional advertising in magazines, and that this exposure is particularly high for precisely those cigarette brands that are most popular among young people.

Perhaps our most striking finding was that between 1986 and 1992, all promotional cigarette advertising in the magazines in our sample appeared in youth magazines with predominantly white, male readership.

This work adds to previous evidence that cigarette companies target young people in their magazine advertising ${ }^{23}$ by demonstrating a specific relationship between promotional cigarette advertisements for youth cigarette brands in magazines with high youth readership. Because of the strong influence of tobacco promotional advertising on smoking behaviour in the young, ${ }^{80-22}$ it now appears that cigarette advertising in magazines may have a particularly important impact on young people. Not only are young people heavily exposed to cigarette advertising in magazines, but they are preferentially exposed to a form of advertising that has been shown to correlate strongly with the initiation of smoking.

The impact of exposure to cigarette promotions may be quite strong. Altman et al found that the odds of a young person being a tobacco user or being susceptible to tobacco use were doubled when they were aware of tobacco promotions, were three times greater if they were aware of tobacco promotions and had an friend who owned a promotional item, were nine times greater if they also personally participated in tobacco promotions, and were 22 times greater if they also had received free tobacco samples. ${ }^{21}$ Pierce et al reported that the relative risk of experimenting with cigarettes or becoming a regular smoker increased by a factor of three for young people who owned a tobacco promotional item. ${ }^{8}$

We caution that our findings are subject to four limitations. First, our definition of youth magazines was based solely on the overall percentage of youth readers, not on the absolute number of youth readers. Many adult magazines in our sample have far greater numbers of youth readers than those we identified as youth magazines. However, we also estimated the actual exposure of all young people (in youth and adult magazines) to cigarette promotional advertising by calculating the number of gross impressions among these youth readers.

Second, this study is measuring only potential exposure to cigarette promotional advertising in magazines. We do not know the actual extent to which young people attend to, and participate in this type of magazine advertising. However, there is evidence to suggest that promotional features of advertising are highly attractive to young people, and that young people tend to participate heavily in such promotions. ${ }^{1} 78$ 18-22 
Third, we did not have access to youth readership data for the years 1980-1985, and used data from 1986 to classify magazines as "youth" or "adult" magazines during this earlier period. We do not believe, however, that changes in youth readership during this period would have been dramatic enough to change the classification of magazines as "youth" or "adult" magazines based on our classification scheme.

Fourth, the LNA data should not be viewed as a comprehensive accounting of all sales promotional features in magazine advertisements for cigarettes. These data include information on major sales promotional features of advertisements, but there is no specific attempt to record and estimate the expenditures for every sales promotional feature appearing in each cigarette advertisement. The fact that this data source is not a comprehensive account of promotional advertising in magazines is perhaps reflected by the instability of the data on annual expenditures for promotional advertising (table 1). Nevertheless, we believe the general trends reflected by the data are most likely accurate, and the fluctuation in the annual data probably does not affect any conclusions drawn from viewing the data as a whole (summing data over the entire study period, as we have done in tables 1 and 2 and figure 3). Because these data are not a comprehensive account of all promotional advertising in magazines, our estimate that $4.6 \%$ of cigarette advertising in magazines represents promotional advertising should be regarded as a lower-bound estimate.

Despite these limitations, our findings, coupled with those of earlier studies, ${ }^{178} 18-22$ call for a closer examination of promotional marketing practices that seem to target youthful readers. Further research should consider the interplay between traditional advertising and sales promotional techniques to capture a complete picture of youth exposure to tobacco marketing. Such research should account for not only youth exposure to advertising and sales promotions, but also the interaction between these two cigarette marketing strategies. All advertising is not the same, even within a seemingly homogenous category like magazine advertising. We found very distinctive patterns of the presence of promotional features in magazine advertisements that suggest a preferential exposure of young people.

Given the magnitude of youth nicotine addiction and the impact promotional activities have on smoking initiation among adolescents, it is important that the public health community has a full understanding of all the facets of cigarette marketing.

This work was supported by a grant from the Massachusetts Department of Public Health, Massachusetts Tobacco Control Program (Health Protection Fund).
1 US Department of Health and Human Services. Preventing tobacco use among young people. A report of the Surgeon General, 1994. Atlanta, Georgia: Public Health Service, Centers for Disease Control and Prevention, Office on Smoking and Health, 1994. (US Government Printing Office Publication No S/N 017-001-00491-0.)

2 Kinnear TC, Bernhardt KL. Principles of marketing, 3rd ed. Glenview, Illinois: Scott, Foresman, 1990.

3 Kotler P. Marketing management: analysis, planning, and control, 3rd ed. Englewood Cliffs, New Jersey: Prentice-Hall, 1976.

4 Kotler P, Roberto EL. Social marketing: strategies for changing public behavior. New York: The Free Press, 1989.

5 Mintz J, Torry S. Internal RJ Reynolds documents detail cigarette marketing aimed at children. Washington Post 1998 Jan 15

6 US Federal Trade Commission. Report to Congress for 1994. Pursuant to the Federal Cigarette Labeling and Advertising Act. Washington, DC: Federal Trade Commission, 1996.

7 Lynch BS, Bonnie RJ, eds. Committee on Preventing Nicotine Addiction in Children and Youths, Division of Biobehavioral Sciences and Mental Disorders, Institute of Medicine. Growing up tobacco free: Preventing nicotine addiction in children and youths. Washington, DC: National Academy Press, 1994.

8 Pierce JP, Choi WS, Gilpin EA, et al. Tobacco industry promotion of cigarettes and adolescent smoking. $\mathscr{f} A M A$ 1998;279:511-5.

9 Warner KE. Tobacco industry response to public health concern: a content analysis of cigarette ads. Health Educ $Q$ 1985;12:115-27.

10 Altman DG, Slater MD, Albright CL, et al. How an unhealthy product is sold: cigarette advertising in magazines, 1960-1985. F Commun 1987;37:95-106.

11 Basil MD, Schooler C, Altman DG, et al. How cigarettes are advertised in magazines: special messages for special markets. Health Commun 1991;5:75-91.

12 King KW, Reid LN, Moon YS, et al. Changes in the visual imagery of cigarette ads, 1954-1986. F Public Policy Market 1991;10:63-80.

13 Huang PP, Burton D, Howe HL, et al. Black-white differences in appeal of cigarette advertisements among adolescents. Tobacco Control 1992;1:249-55.

14 Warner KE, Goldenhar LM. Targeting of cigarette advertising in US magazines, 1959-1986. Tobacco Control 1992; 1:25-30

15 Pollay RW, Lavack AM. The targeting of youths by cigarette marketers: archival evidence on trial. In: McAlister L, Provo, Utah: Association for Consumer Research, Provo, Utah:

16 Albright CL, Altman DG, Slater MD, et al. Cigarette advertisements in magazines: evidence for a differential focus on women's and youth magazines. Health Educ Q 1988; 15:225-33.

17 Pollay RW, Lee JS, Carter-Whitney D. Separate, but not equal: racial segregation in cigarette advertising. $\mathcal{F}$ Advertising 1992;21:45-57.

18 Coeytaux RR, Altman DG, Slade J. Tobacco promotions in the hands of youth. Tobacco Control 1995;4:253-7.

19 Richards JW Jr, DiFranza JR, Fletcher C, et al. RJ Reynolds' "Camel cash": another way to reach kids. Tobacco Control 1995;4:258-60

20 Feighery E, Borzekowski DLG, Schooler C, et al. Seeing, wanting, owning: the relationship between receptivity to tobacco marketing and smoking susceptibility in young people. Tobacco Control 1998;7:123-8.

21 Altman DG, Levine DW, Coeytaux R, et al. Tobacco promotion and susceptibility to tobacco use among adolescents aged 12 through 17 years in a nationally representative sample. Am 7 Public Health 1996;86:1590-3.

22 Evans N, Farkas A, Gilpin E, et al. Influence of tobacco marketing and exposure to smokers on adolescent susceptibility to smoking. $\mathcal{I}$ Natl Cancer Inst 1995;87:1538-45.

23 Leading National Advertisers. Brand detail report (Class G111: cigarettes). New York: Leading National Advertisers, Publishers Information Bureau, 1980-1993.

24 Simmons Market Research Bureau, Inc. Simmons study of media and markets. New York: Simmons Market Research Bureau, Inc., 1980-1993.

25 Teenage Research Unlimited. Teenage Marketing \& Lifestyle Study: Magazine readership data, 1986-1997. Northbrook, Illinois: Teenage Research Unlimited, 1998.

26 Mediamark Research Inc. Mediamark Research Inc. (MRI) teenmark/twelve plus, 1991-1994. New York: Mediamark Research, 1998.

27 King C, Siegel M, Celebucki C, et al. Adolescent exposure to cigarette advertising in magazines: an evaluation of brand-specific advertising in relation to youth readership. fAMA 1998;279:516-20.

28 US Centers for Disease Control and Prevention. Changes in the cigarette brand preferences of adolescent smokersUnited States, 1989-1993. MMWR 1994;43:577-81. 